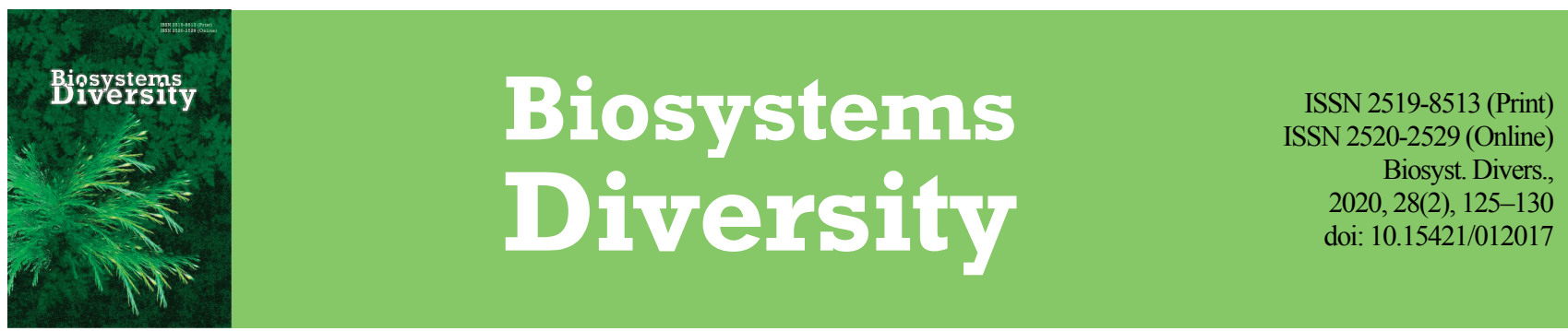

\title{
Biological specifics of exogenous development of Oxyuris equi nematodes (Nematoda, Oxyuridae)
}

\author{
V. O. Yevstafieva*, Y. O. Prykhodko**, O. V. Kruchynenko*, S. M. Mykhailiutenko*, M. S. Kone* \\ *Poltava State Agrarian Academy, Poltava, Ukraine \\ **Kharkiv State Zooveterinary Academy, Kharkiv, Ukraine
}

Article info

Received 03.04.2020

Received in revised form 27.04.2020

Accepted 28.04.2020

Poltava State Agrarian

Academy, Skovorody st., 1/3,

Poltava, 36003, Ukraine.

Tel.: +38-050-183-78-78.

E-mail:evstva@ukr.net

Kharkiv State Zooveterinary Academy, Academichna st., 1

Malaya Danylivka, 62341,

Kharkiv, 62341, Ukraine.

Tel.: +38-066-269-80-90.

E-mail:parasitdad@gmail.com

Yevstafieva, V. O., Prykhodko, Y. O., Kruchynenko, O. V., Mykhailiutenko, S. M., \& Kone, M. S. (2020). Biological specifics of exogenous development of Oxyuris equi nematodes (Nematoda, Oxyuridae). Biosystems Diversity, 28(2), 125-130. doi:10.15421/012017

Helminths of the species Oxyuris equi Schrank, 1788 are pathogens of domestic and wild odd-toed ungulates. They parasitize in the large intestine of horses, causing colitis and dermatitis at the tail root area. The wide distribution and overall persistence of this species is significally promoted by the specifics of its development and reproduction. Here we studied the specifics of the exogenous development of $O$. equi nematodes parasitizing Equidae in respect to the factor of temperature and the morphometric changes in oxyuris eggs at different stages of embryogenesis. In laboratory culture of $O$. equi eggs obtained from female gonads, the embryogenesis occurs in four stages: morula, formation of bean-like embryo, formation of non-invasive larva and formation of infectious larva. The stages of development differ by the morphological parameters. It is established that the development of O. equi eggs is directly related to temperature. The optimal temperature for embryogenesis is $25^{\circ} \mathrm{C}$, at which the highest survival rate of infectious eggs, $81.3 \%$, was observed. At $20^{\circ} \mathrm{C}$ and $15^{\circ} \mathrm{C}$ the survival of eggs decreased during culturing and the ratios of infectious eggs were $75.7 \%$ and $67.3 \%$, respectively. Accordingly, $24.3 \%$ and $32.7 \%$ of eggs died during development. The temperature also affects the duration of development of $O$. equi eggs. At $25^{\circ} \mathrm{C}$, the development of Oxyuris eggs was the fastest and occurred in two days. With temperature falling to 20 and $15^{\circ} \mathrm{C}$, the duration of egg development slowed to three and five days, respectively. The process of embryogenesis in Oxyuris is associated with changes in metrical parameters. The length, width and area of egg surface increased. Length and width of egg plug, and shell width of mature Oxyuris eggs decreased. The obtained data on the duration and specifics of exogenous development of parasitic $O$. equi nematodes will allow effective control measures for horse oxyurosis to be developed.

Keywords: oxyurosis; eggs; embryogenesis; temperature regime; morphometric parameters

\section{Introduction}

Nearly 850 species of nematodes of the order Oxyurida (Weinland, 1858) parasitize the intestine of arthropods and vertebrates, including humans (Adamson, 1994; Ariyarathenam et al., 2010; Kim et al., 2013; Carreno et al., 2014). The levels of specificity of relationships between nematodes and their hosts vary significantly, from strongly specific to the genera including species found in very different hosts (Adamson \& Noble, 1992; Achinelly et al., 2007; Ozawa \& Hasegawa, 2018; Boyko et al., 2019). Oxyurids are haplodiploid, the only such endoparasitic group. The males are haploid and develop from unfertilized eggs, while females, in contrast, are diploid and originate from fertilized eggs (Adamson et al., 1989; Adamson, 1990).

The most common endoparasitic oxyuroses of domestic animals are caused by nematodes of the genera Passalurus Dujardin, 1845 (parasites of rabbits), Skrjabinema Verestchagin, 1926 (sheep), Heterakis Dujardin, 1845 (terrestrial birds and waterfowl), and Oxyuris Rudolphi, 1803 (Shahlapoor, 1965; Georgieva et al., 2005; Zhang et al., 2015; Yevstafyeva et al., 2018; Mykhailiutenko et al., 2019). The latter genus includes $O x y$ uris equi Schrank, 1781, a specific parasite of horses (Equidae). This pathogen is of significant importance in many countries of the world (Dufour et al., 2015; Tedla \& Abichu, 2018; Tydén et al., 2019). For example, prevalence of oxyurosis rates is $1.1-2.3 \%$ in horses of Ethiopia (Sheferaw \& Alemu, 2015; Belay et al., 2016), 7.0\% in Australia (Bucknell et al., 1995), 2.8 4.3\% in Columbia (Ramírez-Hernández et al., 2019), 22.6\% in Iran (Tavassoli et al., 2010), up to $38.7 \%$ in Poland (Slivinska et al., 2016). The parasite has such a wide range due to its biological specifics which depend on the factors of temperature, air and soil humidity, precipitation levels, vegetation cover, etc. (Mfitilodze \& Hutchinson, 1989; Bucknell et al., 1995; Boyko et al., 2009; Reinemeyer \& Nielsen, 2014; Boyko \& Brygadyrenko, 2016). Each living organism is best adapted to the external environmental factors in order to employ all biological abilities for further development, reproduction and persistence. This is considered true for all living creatures. According to that point of view, the parasites are the most adapted life forms of all (McSorley, 2003; Blaxter \& Koutsovoulos, 2015).

Ontogenesis of parasites is usually more complex than that of freeliving species. Indeed, the latter are less encumbered with problems of reproduction and distribution, which are significantly more intricate for parasites. Thus, the majority of parasites often have complex metamorphosis, with the exogenous stages living in various environments for different purposes: dissemination, active growth, passive wait to change the living environment. Parasites can disseminate at different stages of their life cycles. The resting stages allow the parasite to delay its development until the environmental conditions are favourable. In the case of nematodes, such stages are usually eggs (Perry, 2011; Lok, 2016).

Scientists point out the unique life cycle of $O$. equi. After fertilization, the males die. When the female is ready to lay eggs, it travels through the host's intestine to the anal opening and almost fully protrudes outside, using its thin long tail to maintain a link to the anus. This tail is an adaptation biologically useful for females. After the body of female leaves its host, the nematode's vulva begins to excrete a viscous greyish-white mass which adheres to the perianal tissues. This mass consists of numerous eggs and mucus. After laying eggs, the female shrivels and falls from the host. At the host's perineum and under the tail the eggs are exposed to oxygen, the larvae are exposed to optimal 
temperature and humidity. The eggs cannot develop in an oxygen-free medium, thus they need to enter the outer environment (Lee, 2002; Sellon \& Long, 2013). The temperature of the perianal area is unstable ranging $15-30{ }^{\circ} \mathrm{C}$, which is optimal for egg development. They become infectious in 2-3 days. During that time, the sticky film at their surface dries away and they fall off into forage, hay or litter. A small amount of eggs is deposited with fecal masses and develops almost simultaneously after exposure to the environment. Further formation of larva is possible at $22-37^{\circ} \mathrm{C}$ (Wolf et al., 2014; Nielsen \& Reinemeyer, 2018).

The peculiar morphology, biology and ecology of parasitic nematodes, including $O$. equi, indicate the need for a detailed analysis of their biological adaptive properties, required to develop measures for the control and prevention of oxyurosis.

The aim of this work is to study the features of embryogenesis of $O$. equi nematodes in laboratory conditions, taking into account their morphometric changes, as well as the influence of the temperature factor on the survival of oxyuris eggs.

\section{Materials and methods}

Nematodes were collected in helminthological investigation of the intestine of dead or killed horses (Skriabyn, 1928). Species of Oxyuris was identified with (Ivashkyn et al., 1984). The biological features of O. equi nematodes were studied in laboratory cultures of eggs obtained from female nematode gonads. Each egg culture was separately grown in a Petri dish and kept in a thermostat at different temperature regimes $\left(15,20,25^{\circ} \mathrm{C}\right)$ to the development of infectious eggs with infectious larvae (with one-and-a-half bend). Every 12 hours cultures were examined under a microscope. The stage of embryonic development was assessed taking into account the embryonic morphology. Each experiment was done in triplicate. To measure morphometric characteristics of $O$. equi eggs in culture, ImageJ for Windows ${ }^{\circledR}$ (version 2.00) software was used in interactive mode using $10^{\times}, 40^{\times}, 100^{\times}$objective and $10^{\times}$photo eyepiece. To calibrate the image analyzer, a ruled scale of ocular micrometer was calibrated with the scale of stage micrometer included in MikroMed microscope kit. Microphotographs were taken using a digital camera of MikroMed 5 Mpix (China) microscope.

Statistical processing of the experimental results was carried out using Statistica 10 (StatSoft Inc., USA) software. Standard deviation (SD) and average values $(x)$ were calculated. Significance of difference between average values in the studied groups of nematodes was established using one-way analysis of variance and F-test for $95 \%$ confidence level.

\section{Results}

The embryogenesis of horse nematodes of the species $O$. equi in culture occurred in four stages as follows: morula, formation of beanlike embryo, noninfectious larva (once bent), and infectious larva (onceand-a-half bent). These stages were characterized by specific, distinct morphological parameters. $100.0 \%$ of eggs obtained from female gonads were at the stage of morula. Morphologically that manifested as elongated form with a slight unilateral depression, with thick egg shell and a plug on one end. The egg contained dispersed and heterogenous, amorphous mass of greyish-white colour (Fig. 1a). The next stage was characterized by formation of bean-shaped, more solid embryo (Fig. 1b). At the third stage of development, a larva with one bend occurred (Fig. 1c). The formation of an infectious egg was accompanied by slight growth and stronger curve (one-and-a-half bend) of the larva (Fig. 1d).
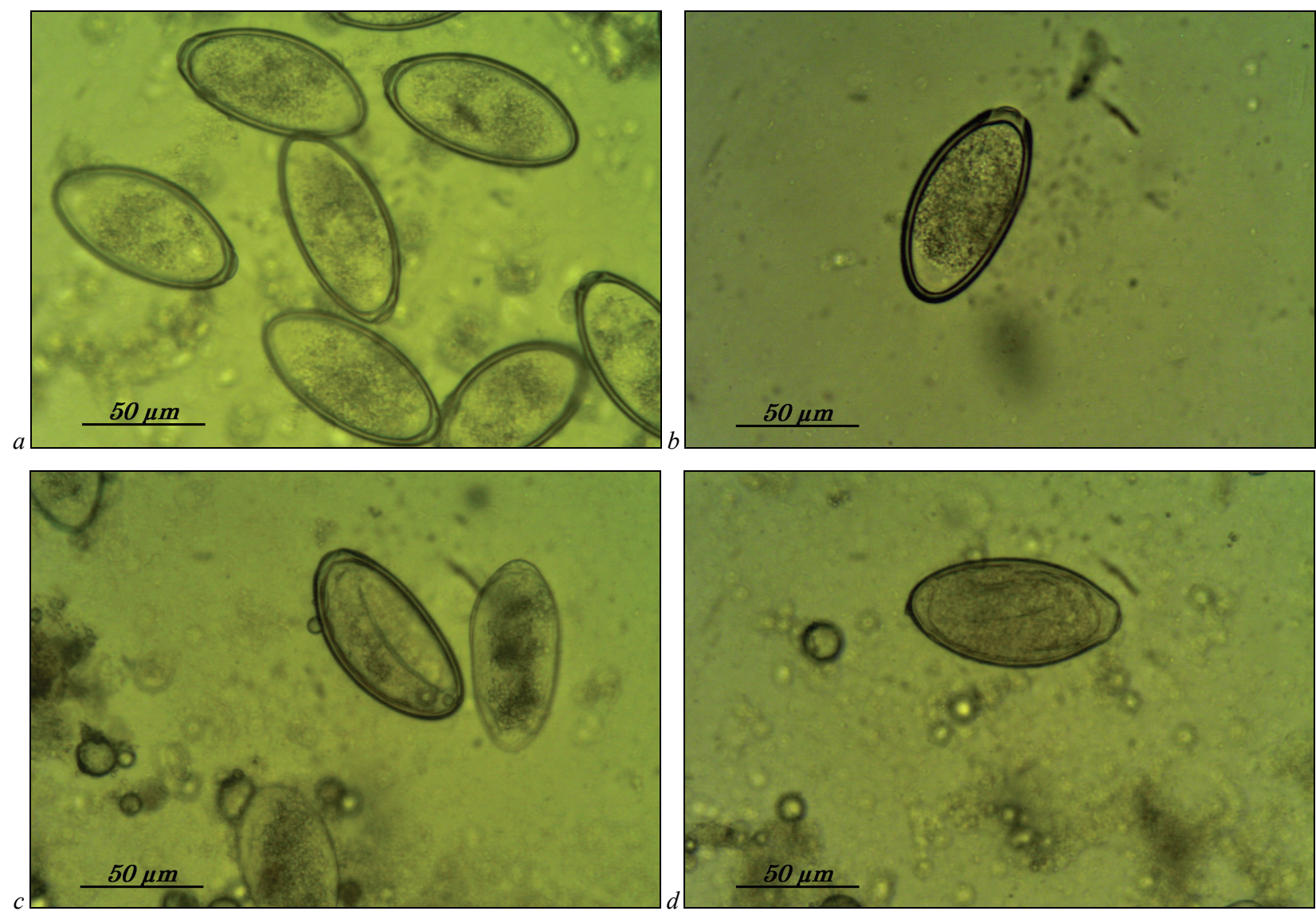

Fig. 1. Stages of embryonic development of nematodes of the species Oxyuris equi: $a$-morula; $b$ - bean-like embryo formation; $c$-formation of once-bent noninfectious larva; $d$-formation of one-and-a-half bent infectious larva

The development of $O$. equi eggs directly depended on the temperature. The oxyuris nematodes developed faster and with higher survival of eggs in warmer culture conditions. Thus, duration of development of $O$. equi eggs was the longest at $15^{\circ} \mathrm{C}$, with the lowest survival ratio. The highest ratio of eggs with infectious larvae was noted at the fifth day of culture, with maximum survival of $67.3 \pm 3.5 \%$ (Table 1 ).

The morula stage lasted two days, with the ratio of eggs containing morulae decreasing to $15.0 \pm 3.0 \%$ in 48 hours. The stage of bean-like 
embryo was recorded on the first to fourth days, peaking $(46.6 \pm 6.0 \%$ and $48.3 \pm 5.5 \%$ ) at $48-60$ hours. Formation of noninfectious larvae occurred from the second to fifth days, with the highest amount (41.3 \pm $7.3 \%$ ) observed in 72 hours, decreasing to $8.3 \pm 3.2 \%$ later. Formation of infectious eggs was noted at the third to fifth days, starting from $4.0 \pm$ $2.0 \%$ in 60 hours. Gradually, that amount increased from $14.6 \pm 1.5 \%$ ( 72 hours) to $67.3 \pm 3.5 \%$ (120 hours). At $15^{\circ} \mathrm{C}$, egg death was noted as early as after 12 hours of development $(19.6 \pm 2.0 \%)$. Subsequently, the ratio of dead eggs increased to $32.6 \pm 3.5 \%$ at the end of embryogenesis (120 hours).

Table 1

Parameters of embryonic development of Oxyuris equi eggs in laboratory culture at $15^{\circ} \mathrm{C}(\mathrm{x} \pm \mathrm{SD}, \mathrm{n}=100)$

\begin{tabular}{lccccc}
\hline & \multicolumn{5}{c}{ Stages of development, \% } \\
\cline { 2 - 5 } $\begin{array}{c}\text { Duration of } \\
\text { culture, } \\
\text { hours/ days }\end{array}$ & Morula & $\begin{array}{c}\text { Bean-like } \\
\text { embryo }\end{array}$ & $\begin{array}{c}\text { Formation } \\
\text { of } \\
\text { non-infecti- } \\
\text { ous larva }\end{array}$ & $\begin{array}{c}\text { Formation } \\
\text { of } \\
\text { infectious } \\
\text { larva }\end{array}$ & $\begin{array}{c}\text { Egg } \\
\text { mortality }\end{array}$ \\
\hline Before culture & 100.0 & - & - & - & - \\
$12 / 1$ & $65.0 \pm 2.6$ & $15.3 \pm 4.0$ & - & - & $19.6 \pm 2.0$ \\
$24 / 1$ & $57.0 \pm 2.0$ & $21.3 \pm 2.5$ & - & - & $21.6 \pm 0.5$ \\
$36 / 2$ & $36.6 \pm 4.0$ & $38.0 \pm 6.2$ & $3.0 \pm 2.6$ & - & $22.3 \pm 1.5$ \\
$48 / 2$ & $15.0 \pm 3.0$ & $46.6 \pm 6.0$ & $14.0 \pm 3.0$ & - & $24.3 \pm 2.5$ \\
$60 / 3$ & - & $48.3 \pm 5.5$ & $22.3 \pm 7.0$ & $4.0 \pm 2.0$ & $25.3 \pm 2.0$ \\
$72 / 3$ & - & $16.3 \pm 6.8$ & $41.3 \pm 7.3$ & $14.6 \pm 1.5$ & $27.6 \pm 1.5$ \\
$84 / 4$ & - & $6.0 \pm 3.0$ & $36.3 \pm 2.8$ & $29.3 \pm 3.2$ & $28.3 \pm 2.0$ \\
$96 / 4$ & - & - & $22.3 \pm 3.0$ & $46.3 \pm 1.1$ & $31.3 \pm 3.0$ \\
$108 / 5$ & - & - & $8.3 \pm 3.2$ & $59.6 \pm 5.5$ & $32.0 \pm 4.0$ \\
$120 / 5$ & - & - & - & $67.3 \pm 3.5$ & $32.6 \pm 3.5$ \\
\hline
\end{tabular}

At $20^{\circ} \mathrm{C}$, the duration of $O$. equi egg development was three days with maximum survival of $75.6 \pm 3.5 \%$, and $24.3 \pm 3.5 \%$ death rate (Table 2).

\section{Table 2}

Parameters of embryonic development of Oxyuris equi eggs in laboratory culture at $20^{\circ} \mathrm{C}(\mathrm{x} \pm \mathrm{SD}, \mathrm{n}=100)$

\begin{tabular}{lccccc}
\hline \multirow{2}{*}{$\begin{array}{c}\text { Duration of } \\
\text { culture, } \\
\text { hours/days }\end{array}$} & Morula & $\begin{array}{c}\text { Bean-like } \\
\text { embryo }\end{array}$ & $\begin{array}{c}\text { Formation } \\
\text { of } \\
\text { non-infecti- } \\
\text { ous larva }\end{array}$ & $\begin{array}{c}\text { Formation } \\
\text { of infectious } \\
\text { larva }\end{array}$ & $\begin{array}{c}\text { Egg } \\
\text { mortality }\end{array}$ \\
\hline Before culture & 100.0 & - & - & - & - \\
$12 / 1$ & $39.0 \pm 2.0$ & $48.3 \pm 5.1$ & - & - & $12.6 \pm 4.0$ \\
$24 / 1$ & $20.0 \pm 4.5$ & $59.0 \pm 8.8$ & $6.6 \pm 3.2$ & - & $14.3 \pm 3.5$ \\
$36 / 2$ & $9.0 \pm 2.0$ & $38.3 \pm 5.1$ & $37.6 \pm 3.0$ & - & $15.0 \pm 2.6$ \\
$48 / 2$ & - & $12.6 \pm 6.0$ & $53.6 \pm 4.7$ & $16.3 \pm 4.5$ & $17.3 \pm 4.5$ \\
$60 / 3$ & - & - & $3.3 \pm 1.5$ & $74.3 \pm 4.0$ & $22.3 \pm 4.0$ \\
$72 / 3$ & - & - & - & $75.6 \pm 3.5$ & $24.3 \pm 3.5$ \\
\hline
\end{tabular}

The morula stage occurred from the first to second days, with the ratio of eggs with morulae gradually decreasing from 100.0 to $9.0 \pm$ $2.0 \%$. The following stage of bean-like embryo formation also occurred over 2 days (up to 48 hours). The maximum amount of eggs at that stage of development was seen after $12(48.3 \pm 5.1 \%)$ and 24 hours $(59.0 \pm 8.8 \%)$ of culture. After 24 hours of culture, the noninfectious larvae were seen in $6.6 \pm 3.2 \%$ of $O$. equi eggs. The maximum amount of eggs at that embryonic stage was found at 48 hours $(53.6 \pm 4.7 \%)$ of culture. After 60 hours, only $3.3 \pm 1.5 \%$ of eggs were at that stage. Infectious eggs developed in 48-72 hours, increasingly, from $16.3 \pm$ $4.5 \%$ to $75.6 \pm 3.5 \%$. Egg death was seen as soon as 12 hours $(12.6 \pm$ $4.0 \%$ ), increasing to $24.3 \pm 3.5 \%$ in 72 hours.

At $25{ }^{\circ} \mathrm{C}, O$. equi eggs developed in two days, and their survival rates were maximum, $81.3 \pm 2.5 \%$. No more than $18.6 \pm 2.5 \%$ eggs died during embryogenesis (Table 3 ).

The morula stage occurred at the first day, the ratio of eggs at that stage gradually decreased from 100.0 to $5.6 \pm 3.5 \%$. The stage of beanlike embryo formation developed after 12-24 hours of culture. The maximum amount of eggs at that stage of development was seen after 12 hours $(58.0 \pm 3.0 \%)$ of culture together with $6.6 \pm 3.0 \%$ of eggs with noninfectious larvae. The maximum amount of noninfectious eggs was found after 24 hours $(40.3 \pm 5.0 \%)$ of culture. After 36 hours, $24.3 \pm$ $4.7 \%$ of eggs were at that stage. Infectious eggs developed in 24 48 hours, increasing from $7.0 \pm 2.0 \%$ to $81.3 \pm 2.5 \%$. Eggs were observed to die at 12 to 48 hours, increasing from $4.0 \pm 4.3 \%$ to $18.6 \pm 2.5 \%$.

Table 3

Parameters of embryonic development of Oxyuris equi eggs in laboratory culture at $25^{\circ} \mathrm{C}(\mathrm{x} \pm \mathrm{SD}, \mathrm{n}=100)$

\begin{tabular}{lccccc}
\hline $\begin{array}{c}\text { Duration of } \\
\text { culture, } \\
\text { hours/days }\end{array}$ & Morula & $\begin{array}{c}\text { Bean-like } \\
\text { embryo }\end{array}$ & $\begin{array}{c}\text { Formation of } \\
\text { non-infectious } \\
\text { larva }\end{array}$ & $\begin{array}{c}\text { Formation } \\
\text { of infectious } \\
\text { larva }\end{array}$ & $\begin{array}{c}\text { Egg } \\
\text { mortality }\end{array}$ \\
\hline Before culture & 100.0 & - & - & - & - \\
$12 / 1$ & $31.3 \pm 2.5$ & $58.0 \pm 3.0$ & $6.6 \pm 3.0$ & - & $4.0 \pm 4.3$ \\
$24 / 1$ & $5.6 \pm 3.5$ & $34.6 \pm 3.7$ & $40.3 \pm 5.0$ & $7.0 \pm 2.0$ & $12.3 \pm 5.0$ \\
$36 / 2$ & - & - & $24.3 \pm 4.7$ & $59.6 \pm 2.5$ & $16.0 \pm 2.6$ \\
$48 / 2$ & - & - & - & $81.3 \pm 2.5$ & $18.6 \pm 2.5$ \\
\hline
\end{tabular}

The metric parameters of $O$. equi eggs changed significantly during embryogenesis. The length and width of eggs obtained from female Oxyuris gonads were $81.8 \pm 1.3$ and $40.5 \pm 1.4 \mu \mathrm{m}$, respectively, at the morula stage. The length and width of the unilateral egg plug were then $3.9 \pm 0.3$ and $10.3 \pm 0.9 \mu \mathrm{m}$. Eggshell was $2.0 \pm 0.0 \mu \mathrm{m}$ thick, and inner egg surface area was $2060 \pm 33 \mu \mathrm{m}^{2}$. Formation of infectious larvae was associated with a significant $(\mathrm{P}<0.001)$ elongation by $3.1 \%(84.5 \pm$ $0.8 \mu \mathrm{m}$, Fig. $2 \mathrm{a})$ and dilatation by $5.4 \%(42.8 \pm 1.2 \mu \mathrm{m}$, Fig. $2 \mathrm{~b})$ of eggs. The inner surface area of eggs increased by $7.4 \%\left(2225 \pm 74 \mu \mathrm{m}^{2}\right.$, Fig. 2f). At the same time, the length of plug in maturing egg decreased by $26.1 \%(2.9 \pm 0.2 \mu \mathrm{m}, \mathrm{P}<0.001$, Fig. $2 \mathrm{c})$, and the width of plug decreased by $10.6 \%(9.2 \pm 0.9 \mu \mathrm{m}, \mathrm{P}<0.01$, Fig. $2 \mathrm{~d})$. The egg shell was thinner by $18.4 \%(1.6 \pm 0.1 \mu \mathrm{m}, \mathrm{P}<0.001)$ in infectious eggs (Fig. $2 \mathrm{e})$.

Thus, studies of adaptation of parasites during the exogenous development are economically and theoretically significant for understandding their abilities to adapt as part of species establishment and formation of parasite-host relationships. The life cycle of $O$. equi nematodes is specifically dependent on the optimal temperature for the parasitic embryo to develop, the temperature regime corresponding to that of the host animal. These conditions are important for the growth, development and maturing of eggs, ensuring their high survival rates.

\section{Discussion}

We have obtained new data on the features of exogenous development for eggs of Oxyuris equi Schrank, 1781 nematode parasites of oddtoed ungulates. Many scientists consider $O$. equi to be one of the most common parasites of horses (Equus Linnaeus, 1880) worldwide. The prevalence of oxyurosis in domestic horses can be as high as 38.7\% (Dunsmore \& Jue Sue, 1985; Tavassoli et al., 2010; Slivinska et al., 2016), and infection rates can be higher than 10000 nematodes per horse (Boxell et al., 2004). This significant distribution of oxyurosis in horses is explained by the parasite's specific adaptations to environmental factors. The infection rates are higher in horses from areas with evenly distributed high precipitation; hence the latter is advantageous for the development of O. equi (Mfitilodze \& Hutchinson, 1989; Bucknell et al., 1995).

This parasitic situation is notably unpredictable and adversely fluctuating, and rooted in the growing anthropogenic pressure on ecosystems. When the balance in parasitic systems is disturbed, it is accompanied by growing rates of usual infections and appearance of new genetic variations of pathogens (Cable et al., 2017; Rogalski et al., 2017). This remains an acute problem despite the progress with measures of pathogen control for plants and animals. Parasitic organisms have high reproductive and adaptive potential and in high numbers can cause significant damage to the health and productivity of animals.

These problems are especially acute against the backdrop of global processes such as climate change and biodiversity reduction (Genchi et al., 2009; Short et al., 2017). Parasites are one of the most important factors regulating the dynamics of animal populations in nature. Among other factors, they regulate animal abundance, frequently presenting a mechanism of natural selection of suitable specimens and populations (Smyth, 
1994; Hubálek, 2003; Horwitz \& Wilcox, 2005). However, the real mechanisms of the exogenous development of parasites, including $O$. equi, are still largely unknown. We have found that embryogenesis of $O$. equi in laboratory conditions occurred in four stages (morula, formation of bean-like embryo, noninfectious larva (once bent) formation, and infectious larva formation (with one-and-a-half bend). The stages were morphometrically distinct. The oxyuris egg was elongated, with slight unilateral depression, thick eggshell and a unilateral egg plug. The eggs obtained from female $O$. equi gonads had the following mean values of metric parameters: length and width of egg -81.8 and $40.5 \mu \mathrm{m}$, length and width of plug -3.9 and $10.3 \mu \mathrm{m}$, egg shell thickness $2.0 \mu \mathrm{m}$, area of inner surface $2060 \mu \mathrm{m}^{2}$. The morula stage was characterized by presence of dispersed heterogenous amorphous mass of greyish-white colour in eggs. The stage of bean-like embryo was observed as formation of a more condensed embryo of aforementioned shape. Stage of non-infectious larva formation was characterized by appearance of once bent larva in the egg. At this stage, the larva had a noticeable lumen of the future intestine. The de- velopment of an infectious larva was characterized by the formation of a larger larva, bent one and a half times, in the egg. At this stage, the larvae had a clearly seen bulb on the esophagus. A similar development of $O$. equi was described in another study, where the authors did not distinguish clear developmental stages yet noted a similar larval formation in the oxyuris egg (Skrjabin et al., 1967). According to them, the formation of the O. equi egg begins in the initial part of the female's ovary, where the egg is first covered in shell. Such embryo is oval and consists of numerous cleaving spheres. Later, the gastrulation occurs with the longitudinal blastule invagination. The invagination narrows in the middle, acquiring an elongated and somewhat bent shape. Further on, one end of the embryo elongates and begins to curve around the opposite egg wall. The larva is described as once bent when its pointed tail end reaches the opposite egg tip. Subsequent larval development is associated with the tail end reaching the egg tip where it began to curve, resulting in one and a half bend of an infectious larva. According to other authors, egg development is as follows: morula, first, second, and third (infectious) stage larva (Lamann, 2010).
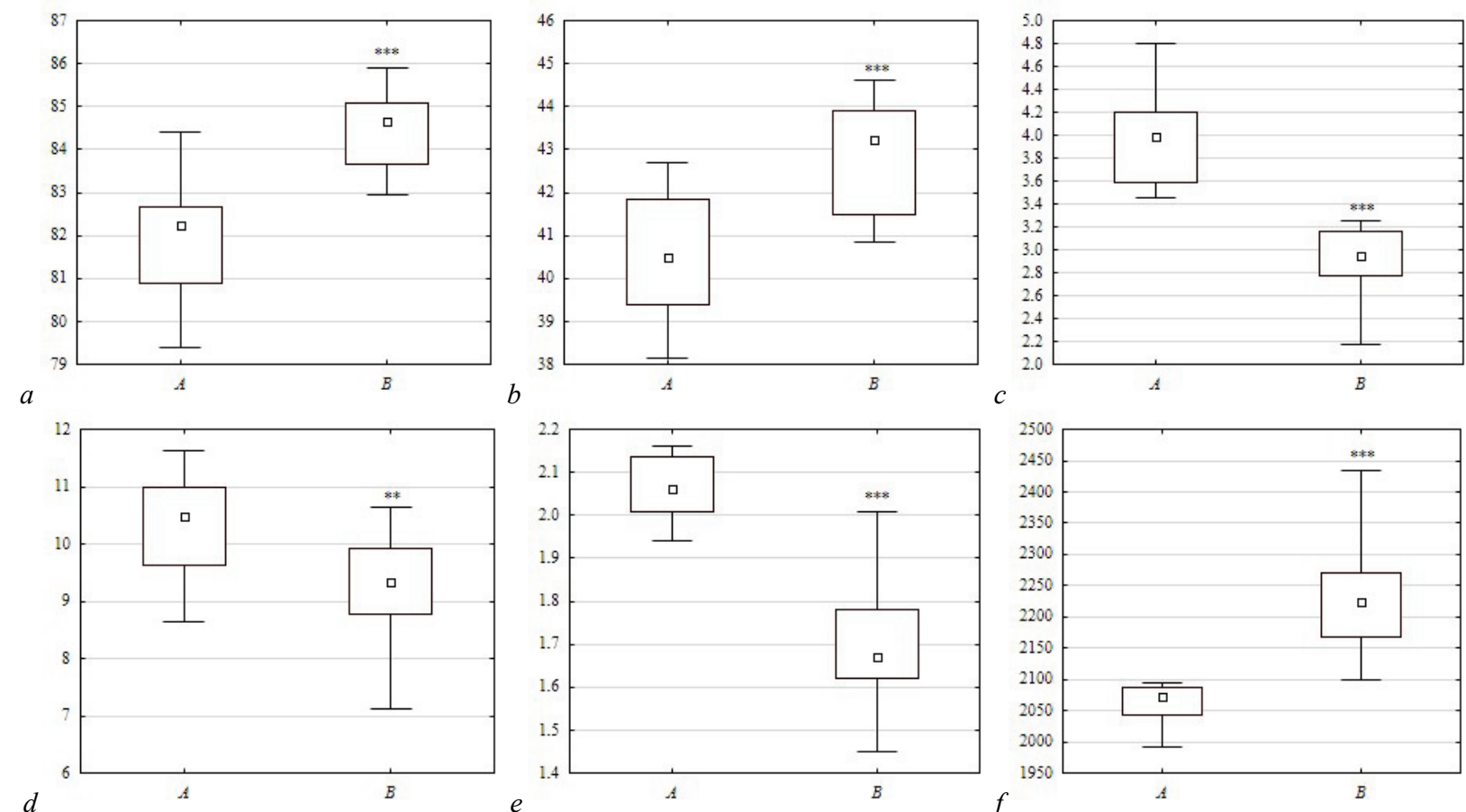

Fig. 2. Metric parameters of Oxyuris equi eggs during embryogenesis: $a$ - egg length, $b$ - egg width, $c$ - egg plug length, $d$ - egg plug width, $e$ - egg shell thickness $(\mu \mathrm{m}), f$-inner surface area $\left(\mu \mathrm{m}^{2}\right) ; A$ - morula stage, $B$-infectious egg stage; $* *-\mathrm{P}<0.01, * * *-\mathrm{P}<0.001$ compared to values of egg parameters at morula stage $(\mathrm{n}=20, \mathrm{x} \pm \mathrm{SD})$

We also have observed the development of $O$. equi eggs to directly depend on the temperature. They developed faster and survival in the outer environment increased when the temperature of the culture was higher. Thus, culturing $O$. equi eggs at $15^{\circ} \mathrm{C}$ resulted in the longest duration of development and lowest survival rate. The maximum number of infectious eggs was seen at the fifth day of culture with the survival rates of $67.3 \pm 3.5 \%$. At $20^{\circ} \mathrm{C}$, the duration of egg O. equi development decreased to three days and the survival was higher, to $75.6 \pm$ $3.5 \%$. The optimal temperature for exogenous development and survival of oxyuris eggs was $25^{\circ} \mathrm{C}$. Then, the duration of development was two days with $81.3 \pm 2.5 \%$ survival.

The exogenous development of $O$. equi eggs in the outer environment is partially described in a number of reports. In several studies, the embryonic development of oxyuris parasites of domestic horses is thought to directly depend on the temperature and humidity of pasture biotopes. At mean air temperature of $10.7^{\circ} \mathrm{C}$, the development occurs in 14 days, compared to 10 days at $18.6^{\circ} \mathrm{C}$. It is also suggested that summer is the most favourable season for $O$. equi egg development, which occurred in two to three days at mean temperatures ranging 24.6 $29.3{ }^{\circ} \mathrm{C}$. In autumn months, the eggs become infectious more slowly with the decreasing temperature. At $20.6{ }^{\circ} \mathrm{C}$, Oxyuris eggs mature in four days, and at $16.0^{\circ} \mathrm{C}$ they develop in six days. At $10.2^{\circ} \mathrm{C}$, the embryonic development also occurs but not to the infectious stage (Arip- sheva et al., 2010). Interestingly, there are data on embryonic development of oxyuris parasites of the inland bearded dragon (Pogona vitticeps). It is found that Oxyuris thelandros eggs develop in 48 hours in the feces of bearded dragons kept in a terrarium at $24-26^{\circ} \mathrm{C}$ day time and $19^{\circ} \mathrm{C}$ at night-time temperature (which is temperature optimum for the reptiles). The observed stages of development are blastomere cleavage and formation of infectious larvae (Stojanov \& Bogach, 2018).

We also measured changes in the metric parameters of $O$. equi eggs during embryogenesis. We proved that oxyuris eggs development is associated with increasing length (by $3.1 \%, \mathrm{P}<0.001$ ), width (by $5.4 \%$, $\mathrm{P}<0.001$ ), and area of inner egg surface (by $7.4 \%, \mathrm{P}<0.001$ ). The length, width of egg plug and eggshell thickness decreased by $26.1 \%$, $10.6 \%$, and $18.4 \%$, respectively $(\mathrm{P}<0.01 \ldots 0.001)$. To our knowledge, these findings have not been reported before.

We support the conclusions of other studies (Wolf et al., 2014; Nielsen \& Reinemeyer, 2018) that the direct dependence of $O$. equi embryogenesis on temperature regime is a result of the evolution of a life cycle which involves most of the exogenous development taking place on the host's body (perianal area) with stable favourable temperature conditions.

Thus, the definitive hosts which have the mature parasites and their developing exogenous stages effectively support the survival of nematodes and expand their range. 


\section{Conclusion}

The exogenous development of eggs of Oxyuris equi (Schrank, 1781) which are specific parasites of horses is observed in laboratory culture to directly depend on temperature. The warmer it is, the faster the eggs develop and become infectious, and the survival of embryonic stages is also higher. The duration of development is two days with $81.3 \pm 2.5 \%$ survival at $25{ }^{\circ} \mathrm{C}$. At 20 and $15{ }^{\circ} \mathrm{C}$, the embryogenesis proceeds in three and five days, with $75.6 \pm 3.5 \%$ and $67.3 \pm 3.5 \%$ survival, respectively. The exogenous development of eggs obtained from $O$. equi female gonads occurs in stages. We observed four stages of embryogenesis: morula, formation of bean-like embryo, formation of non-infectious and infectious larvae. The duration of these stages depends on temperature and is 24-48 hours for morulae, 24-84 hours for bean-like embryos, 36-108 hours for noninfectious larvae and 48120 hours for infectious larvae. The stages have distinctly different morphological and metric parameters. Formation of eggs containing infectious larvae of $O$. equi is associated with increasing length, width and inner surface area of eggs, and decreasing eggshell thickness and length and width of the unilateral egg plug. The presented results on the biological specifics of parasitic nematodes are important both academically and to develop control measures against that pathogen.

\section{References}

Achinelly, M. F., \& Camino, N. B. (2007). A new species of Blatticola Schwenk, 1926 (Oxyurida, Thelastomatidae) a parasite of Anurogryllus muticus (De Geer, 1773) (Orthoptera, Gryllidae) from Argentina. Papéis Avulsos de Zoologia, 47(15), 181-186.

Adamson, M. (1994). Evolutionary patterns in life histories of Oxyurida. International Journal for Parasitology, 24(8), 1167-1177.

Adamson, M. L. (1989). Evolutionary biology of the Oxyurida (Namatoda): Biofacies of a haplodiploid taxon. Advances in Parasitology, 28, 175-228.

Adamson, M. L. (1990). Haplodiploidy in the Oxyurida: Decoupling the evolutionary processes of adaptation and speciation. Annales de Parasitologie Humaine et Comparée, 65(1), 31-35.

Adamson, M. L., \& Noble, S. (1992). Structure of the pinworm (Oxyurida: Nematoda) guild in the hindgut of the American cockroach, Periplaneta americana. Parasitology, 104(3), 497-507.

Aripsheva, B. M., Bittirov, A. M., \& Kanokova, A. S. (2010). Jekologo-jepizootologicheskaja harakteristika oksiuroza loshadej v Kabardino-Balkarskoj Respublike [Features of ecology and epizootology of oxyurosis of horses in the Kabardino-Balkarian Republic]. Russian Journal of Parasitology, 2, 24-28 (in Russian).

Ariyarathenam, A. V., Nachimuthu, S., Tang, T. Y., Courtney, E. D., Harris, S. A., \& Harris, A. M. (2010). Enterobius vermicularis infestation of the appendix and management at the time of laparoscopic appendectomy: Case series and literature review. International Journal of Surgery, 8, 466-469.

Belay, W., Teshome, D., \& Abiy, A. (2016). Study on the prevalance of gastrointestinal helminthes infection in equines in and around Kombolcha. Journal of Veterinary Science and Technology, 7(5), 367-372.

Blaxter, M., \& Koutsovoulos, G. (2015). The evolution of parasitism in Nematoda. Parasitology, 142(1), 26-39.

Boxell, A. C., Gibson, K. T., Hobbs, R. P., \& Thompson, R. C. A. (2004). Occurrence of gastrointestinal parasites in horses in metropolitan Perth, Western Australia. Australian Veterinary Journal, 82, 91-95.

Boyko, A., Brygadyrenko, V., Shendryk, L., \& Loza, I. (2009). Estimation of the role of antropo-zoonosis invasion agents in the counteraction to bioterrorism. Counteraction to Chemical and Biological Terrorism in East European Countries. NATO Science for Peace and Security Series A: Chemistry and Biology. Springer Nature, 309-315.

Boyko, A. A., \& Brygadyrenko, V. V. (2016). Influence of water infusion of medicinal plants on larvae of Strongyloides papillosus (Nematoda, Strongyloididae). Visnyk of Dnipropetrovsk University, Biology, Ecology, 24(2), 519-525.

Boyko, O. O., Gugosyan, Y. A., Shendrik, L. I., \& Brygadyrenko, V. V. (2019) Intraspecific morphological variation in free-living stages of Strongyloides papillosus (Nematoda, Stronfyloididae) parasitizing various mammal species. Vestnik Zoologii, 53(4), 313-324.

Bucknell, D., Gasser, R., \& Beveridge, I. (1995). The prevalence and epidemiology of gastrointestinal parasites of horses in Victoria, Australia. International Journal for Parasitology, 25, 711-724.

Cable, J., Barber, I., Boag, B., Ellison, A. R., Morgan, E. R., Murray, K., Pascoe, E. L., Sait, S. M., Wilson, A. J., \& Booth, M. (2017). Global change, parasite transmission and disease control: Lessons from ecology. Philosophical
Transactions of the Royal Society of London. Series B, Biological Sciences, 372(1719), 20160088

Carreno, R. A. (2014). The systematics and evolution of pinworms (Nematoda: Oxyurida: Thelastomatoidea) from invertebrates. Journal of Parasitology, $100(5), 553-560$

Dufour, B., Hugot, J. P., Lepetz, S., \& Le Bailly, M. (2015). The horse pinworm (Oxyuris equi) in archaeology during the Holocene: Review of past records and new data. Infection, Genetics and Evolution, 33, 77-83.

Dunsmore, J., \& Jue Sue, L. P. (1985). Prevalence and epidemiology of the major gastrointestinal parasites of horses in Perth, Western Australia. Journal of Equine Veterinary Science, 17, 208-213.

Genchi, C., Rinaldi, L., Mortarino, M., Genchi, M., \& Cringoli, G. (2009). Climate and Dirofilaria infection in Europe. Veterinary Parasitology, 163, 286-292.

Georgieva, K., Yoneva, A., Mizinska-Boevska, Y., \& Todev, I. (2005). Ultrastructure of the contact surfaces of Passalurus ambiguus (Rudolphi, 1819) (Nematoda). Acta Biologica Hungarica, 56(3-4), 297-303.

Horwitz, P., \& Wilcox, B. A. (2005). Parasites, ecosystems and sustainability: An ecological and complex systems perspective. International Journal for Parasitology, 35(7), 725-732.

Hubálek, Z. (2003). Emerging human infectious diseases: Anthroponoses, zoonoses and sapronoses. Emerging Infectious Diseases, 9(3), 403-404.

Ivashkin, V. M., \& Dvojnos, G. M. (1984). Opredelitel' gel'mintov loshadej [Identification key to helminthes of horses]. Naukova Dumka, Kyiv (in Russian).

Kim, D. H., Cho, M. K., Park, M. K., Kang, S. A., Kim, B. Y., Park, S. K., \& Yu, H. S. (2013). Environmental factors related to enterobiasis in a southeast region of Korea. Korean Journal of Parasitology, 51, 139-142.

Lamann, G. V. (2010). Veterinary parasitology. Nova Biomedical Press, New York.

Lee, D. L. (2002). The biology of nematodes. CRC Press, London.

Lok, J. B. (2016). The developmental biology of parasitic nematodes. PLOS Pathogens, 12(3), e1005328.

McSorley, R. (2003). Adaptations of nematides to environmental extremes. Florida Entomologist, 86(2), 138-142.

Mfitilodze, M., \& Hutchinson, G. (1989). Prevalence and intensity of non-strongyle intestinal parasites of horses in Northern Queensland. Australian Veterinary Journal, 66, 23-26.

Mykhailiutenko, S. M., Kruchynenko, O. V., Klymenko, O. S., Serdioucov, J. K. Dmytrenko, N. I., \& Tkachenko, V. V. (2019). Pathomorphological changes in the large intestine of rabbits parasitised by Passalurus ambiguus (Nematoda, Oxyuridae). Regulatory Mechanisms in Biosystems, 10(1), 69-74.

Nielsen, M. K., \& Reinemeyer, C. R. (2018). Handbook of equine parasite control. Wiley-Blackwell, New York.

Orpin, J. B., Mzungu, I., \& Hussaini, M. S. (2019). Prevalence of geohelminth parasites of horses in dutsinma metropolis, Katsina State Nigeria. Journal of Advances in Biology and Biotechnology, 20(2), 1-7.

Ozawa, S., \& Hasegawa, K. (2018). Broad infectivity of Leidynema appendiculatum (Nematoda: Oxyurida: Thelastomatidae) parasite of the smokybrown cockroach Periplaneta fuliginosa (Blattodea: Blattidae). Ecology and Evolution, 8, 3908-3918.

Perry, R. N. (2011). Understanding the survival strategies of nematodes. CAB Reviews: Perspectives in agriculture veterinary science nutrition and natural resources, 6 .

Ramírez-Hernández, A., Polo, G., Robayo-Sáncheza, L. N., Cruz-Maldonadoa, O. A., Imbacuán-Pantojaa, W. O., \& Cortés-Vecinoa, J. A. (2019). Gastrointestinal and pulmonary parasites of working horses from Colombia. Veterinary Parasitology: Regional Studies and Reports, 17, 100296.

Reinemeyer, C. R., \& Nielsen, M. K. (2014). Review of the biology and control of Oxyuris equi. Equine Veterinary Education, 26(11), 584-591.

Rogalski, M. A., Gowler, C. D., Shaw, C. L., Hufbauer, R. A., \& Duffy, M. A. (2017). Human drivers of ecological and evolutionary dynamics in emerging and disappearing infectious disease systems. Philosophical Transactions of the Royal Society of London. Series B, Biological Sciences, 372(1712), 20160043

Sellon, D. C., \& Long, M. (2013). Equine infectious diseases. Saunders Elsevier, Philadelphia.

Shahlapoor, A. A. (1965). A note on the identification of Skrjabinema ovis (Skrjabin, 1915) and Trichostrongylus spp. in sheep and goats in Iran. Journal of Helminthology, 39(2-3), 273-276.

Sheferaw, D., \& Alemu, M. (2015). Epidemiological study of gastrointestinal helminths of equines in Damot-Gale district, Wolaita zone, Ethiopia. Journal of Parasitic Diseases, 39(2), 315-320.

Short, E. E., Caminade, C., \& Thomas, B. N. (2017). Climate change contribution to the emergence or re-emergence of parasitic diseases. Infectious Diseases, 10,1178633617732296

Skjabin, K. I., Shikhobalova, N. P., \& Lagodovskaya, E. A. (1967). Osnovy nematodologii. Oksiuraty [Essentials of nematodology. Oxyurates]. Nauka, Moscow (in Russian). 
Skrjabin, K. I. (1928). Metod polnyh gel'mintologicheskih vskrytij pozvonochnyh, vkljuchaja cheloveka [The method of complete helminthological autopsy of vertebrates, including humans]. Moscow State University, Moscow (in Russian).

Slivinska, K., Kharchenko, V., Wróblewski, Z., Gawor, J., \& Kuzmina, T. (2016) Parasitological survey of Polish primitive horses (Equus caballus gmelini Ant.): Influence of age, sex and management strategies on the parasite community. Helminthologia, 53(3), 233-242.

Smyth, J. D. (1994). Introduction to animal parasitology. Third ed Cambridge University Press, Cambridge.

Stoyanov, L. A., \& Bogach, M. V. (2018). Diagnostyka oksiurozu borodatyh agam (Pogona vitticeps) [Diagnostics of oxyuriasis in bearded dragons (Pogona vitticeps)]. Agrarian Bulletin Prichernomorya, 91, 122-127 (in Ukrainian).

Tavassoli, M., Dalir-Naghadeh, B., \& Esmaeili-Sani, S. (2010). Prevalence of gastrointestinal parasites in working horses. Polish Journal of Veterinary Sciences, 13, 319-324.
Tedla, M., \& Abichu, B. (2018). Cross-sectional study on gastro-intestinal parasites of equids in South-Western Ethiopia. Parasite Epidemiology and Control, 3(4), e00076.

Tyden, E., Jansson, A., \& Ringmark, S. (2019). Parasites in horses kept in a 2.5 year-round grazing system in nordic conditions without supplementary feeding. Animals, 9(12), 1156.

Wolf, D., Hermosilla, C., \& Taubert, A. (2014). Oxyuris equi: Lack of efficacy in treatment with macrocyclic lactones. Veterinary Parasitology, 201, 163-168.

Yevstafyeva, V. A., Melnychuk, V. V., Nikiforova, O. V., Suprunenko, K. V., Korchan, L. N., Lokes-Krupka, T. P., Nehrebetskyi, I. S., \& Korchan, N. I. (2018). Comparative morphology and biology of nematodes of genus Heterakis (Nematoda, Heterakoidea), parasites of the domestic goose (Anser anser) in Ukraine. Regulatory Mechanisms in Biosystems, 9, 229-236.

Zhang, Y., Xu, W. W., Guo, D. H., Liu, Z. X., Duan, H., Su, X., Fu, X., Yue, D. M., Gao, Y., \& Wang, C. R. (2015). The complete mitochondrial genome of $O x y$ uris equi: Comparison with other closely related species and phylogenetic implications. Experimental Parasitology, 159, 215-221. 